DOI https://doi.org/10.15589/znp2019.3(477).6 УДК 004.421:672

\title{
ANALYSIS OF QUANTITATIVE CHARACTERISTICS OF MICROSTRUCTURES SYNTHESIZED BY METHOD OF PROBABILISTIC CELLULAR AUTOMATA
}

\section{АНАЛІЗ КІЛЬКІСНИХ ХАРАКТЕРИСТИК МІКРОСТРУКТУР, СИНТЕЗОВАНИХ МЕТОДОМ ІМОВІРНІСНИХ КЛІТКОВИХ АВТОМАТІВ}

\author{
Oleksii O. Vodka \\ oleksii.vodka@gmail.com \\ ORCID: 0000-0002-4462-9869
}

\author{
О. О. Водка, \\ канд. техн. наук, доцент
}

\section{National Technical University “Kharkiv Polytechnic Institute”, Kharkiv}

Начіональний технічний університет «Харківський політехнічний інститут», м. Харків

\begin{abstract}
The micro-level metallic materials are a polycrystalline structure. Each crystal of this structure has its own shape and orientation in space. This leads to the fact that the set of shapes and orientations of the crystal determines the mechanical characteristics of the material. Thus, it is important to model the microstructures of materials. It allows to determine the mechanical parameters of the materials based on their microstructure. The cellular automaton method is widely used in modeling the microstructure of various materials. Cellular automata are widely used to predict behavior in different industries. In this paper software for synthetic generation of microstructure of polycrystalline materials is developed. The software allows to synthetically generate the microstructure of a material using different cell neighborhood rules. The process of crystallization from a physical point of view must occur uniformly in all directions. Due to local fluctuations and temperature gradients, the uneven volume of the chemical composition of the melt crystallizes unevenly in different directions. In order to model this effect, it is proposed to set the crystallization rate in the form of an ellipse. The ellipse radii correspond to the crystallization rate in the respective directions. To determine the transition probabilities, an ellipse is projected onto field cells. Then determine the area of the ellipse that hit each cell. The cell areas obtained represent crystallization probabilities in different directions. The quantitative characteristics of microstructures are investigated on the basis of microstructures generated. The software determines the shape factor, the normalized grain area, the scale factor and the grain orientation angle. The data obtained are statistically processed and the probability density functions obtained. According to statistical parameters, the obtained results are compared with the parameters of the microstructure of pure iron.
\end{abstract}

Key words: method cellular automata; microstructure of the material; quantitative characteristics; probability.

Анотація. На мікрорівні металеві матеріали являють собою полікристалічну структуру. Кожен кристал цієї структури має свою форму й орієнтацію у просторі. Це приводить до того, що сукупність форм і орієнтацій кристала визначає механічні характеристики матеріалу. Отже, важливо моделювати мікроструктури матеріалів. Це дасть змогу визначати механічні параметри матеріалів на основі їхньої мікроструктури. Метод кліткових автоматів широко використовується в моделюванні мікроструктури різних матеріалів. Моделі на основі кліткових автоматів широко використовуються для прогнозування поведінки в різних галузях. У роботі розроблено програмне забезпечення для синтетичної генерації мікроструктури полікристалічних матеріалів. Програмне забезпечення дозволяє синтетично згенерувати мікроструктуру матеріалу, використовуючи різні правила сусідства клітинок. Процес кристалізації з фізичного погляду повинен відбуватись рівномірно в усіх напрямках. Через локальні флуктуації та градієнти температури, нерівномірність за об'ємом хімічного складу розплаву кристалізація відбувається нерівномірно в різних напрямках. Для моделювання цього ефекту в роботі пропонується задавати швидкість кристалізації у вигляді еліпса. Радіуси еліпса відповідають швидкості кристалізації у відповідних напрямках. Для визначення ймовірностей переходу еліпс проєктується на клітинки поля. Після чого визначається площа еліпса, що потрапила в кожну клітинку. Отримані площі клітинок - імовірності кристалізації в різних напрямках. На основі згенерованої мікроструктури проводиться дослідження кількісних характеристик мікроструктур. За допомогою програмного забезпечення визначено коефіцієнт форми, нормовану площу зерна, масштабний коефіцієнт і кут орієнтації зерен. Для отриманих даних проведена статистична обробка й отримані функції щільності ймовірності. За статистичними параметрами виконано порівняння отриманих результатів із параметрами мікроструктури чистого заліза.

Ключові слова: метод кліткових автоматів; мікроструктура матеріалу; кількісні характеристики; імовірність. 


\section{КОМП'ЮТЕРНІ НАУКИ ТА ІНФОРМАЦІЙНІ ТЕХНОЛОГІЇ №3ロ 2019}

\section{ПОСТАНОВКА ЗАДАЧІ}

На мікрорівні металеві матеріали являють собою полікристалічну структуру. Кожен кристал цієї структури має свою форму й орієнтацію у просторі. Це приводить до того, що сукупність форм і орієнтацій кристала визначають механічні характеристики матеріалу. Отже, важливо моделювати мікроструктури матеріалів. Це дасть змогу визначати механічні параметри матеріалів на основі їхньої мікроструктури.

Одним із поширених методів для моделювання мікроструктури матеріалів є метод клітинних автоматів. Кліткові автомати почали використовуватись у середині XX ст. [1-3]. Під терміном «клітковий автомат» розуміють сукупності залежних елементів із заданими станами і правилами. Ці правила визначають стани цих елементів, залежності між ними змінюються в часі. Час і стани водночас дискретні. Використання описаних моделей для формального моделювання самовідтворюваних організмів вперше запропоновано в роботі Дж. фон Неймана [2]. Елементи кліткових автоматів запропоновано представити одновимірними, двовимірними або багатовимірними нескінченними прямокутними таблицями. Стан елемента змінюється залежно від його стану і від стану найближчих сусідів.

Моделі на основі кліткових автоматів широко використовуються для прогнозування поведінки в різних галузях. Так, моделювання за допомогою кліткових автоматів використовується у криптографії [4; 5], обробці зображень [6-9], біології [10-12], фізиці [13, 14]. Усі ці роботи охоплюють багато можливостей застосування методу кліткових автоматів. Однак варто зазначити як одне із найбільш вдалих застосування методу в галузі матеріалознавства. Розроблено багато модифікацій методу для моделювання процесів кристалізації, рекристалізації й еволюції внутрішньої структури матеріалів [15-25]. У більшості робіт метод клітинних автоматів використовується для синтетичного відтворення мікроструктури матеріалів. Проте в зазначених роботах майже не досліджується вплив параметрів кліткових автоматів на якість створених мікроструктур. Також для збільшення можливостей моделювання процесів, що мають стохастичну природу, розроблено модифікацію методу - імовірнісний метод кліткових автоматів [15-17].

Варто відзначити роботу [16]. У праці частково досліджуються розподіли розмірів зерен. Однак моделювання виконується на гексагональній сітці. Отже, майже немає праць, присвячених дослідженню якості синтетично створених мікроструктур та їхньої статистичної відповідності реальним мікроструктуpam.

\section{МЕТА ДОСЛІДЖЕННЯ}

У роботі пропонується розробити програмне забезпечення, що дозволяє моделювати мікроструктуру металів із використанням імовірнісного методу кліт- кових автоматів. Для цього необхідно виконати такі завдання:

- $\quad$ вивчити розроблені модифікації методу кліткових автоматів моделювання мікроструктур;

- розробити програмне забезпечення, що дозволяє моделювати мікроструктури металів за заданими випадковим чином центрами зерен;

протестувати роботу ПЗ, визначити статистичні характеристики розмірів, форми й орієнтації зерен;

- порівняти отримані результати з реальними мікроструктурами.

\section{МОДЕЛЮВАННЯ ЗА ДОПОМОГОЮ КЛІТКОВИХ АВТОМАТІВ}

Клітковий автомат K 3 математичного погляду [26-28] - це впорядкована множина із чотирьох компонентів:

$$
K=<z^{d}, N, A, \varphi>
$$

де $z^{d}$ - множина $d$-мірних векторів із цілочисельними координатами - клітковий простір; $N=\left\{n_{i} \mid n_{i}=\left(x_{1 i}, \ldots, x_{d i}\right), \exists n_{i}=0\right\}, i=1, \ldots, m$ - скінченна множина потужності $m$ векторів із $z^{d}$ із нульовим вектором - шаблон сусідства клітинки; $A$ - скінченна множина потужності $k$ станів клітинки 3 виділеним станом спокою $\varnothing$ - алфавіт кліткового автомата; $\varphi-$ локальна функція переходів, визначена в дискретні моменти часу, яка змінює стани клітинки, що є нульовим елементом у шаблоні, залежно від стану клітинок, що складають шаблон сусідства $\varphi: A^{m} \rightarrow A$; водночас $\varphi(\varnothing, \varnothing, \ldots, \varnothing)=\varnothing$.

Стан усіх клітинок у момент часу $t$ створює поточну конфігурацію $c^{t}: z^{d} \rightarrow A$.

Застосування локальної функції переходів до поточної конфігурації задає глобальну функцію переходів $c_{j 1}=g\left(c_{j}\right)$. Впорядкована сукупність конфігурацій, що отримується 3 початкової послідовним застосуванням глобальної функції переходів, утворює еволюцію $е$ кліткового автомата: $e=\left\langle c_{0}, c_{1}, \ldots, c_{s}\right\rangle$ [26-28].

Усі клітинки утворюють решітку кліткового автомата. Решітки можуть бути різних типів, відрізняючись як за розмірністю, так і за формою клітинок. Кожна клітинка $є$ скінченним автоматом, стани якого визначаються станами сусідніх клітинок і їі власними станами.

Кліткові автомати в загальному випадку характеризуються такими властивостями:

1. Зміна значень усіх клітинок відбувається одночасно після обчислення нового стану кожної клітинки решітки.

2. Решітка однорідна. Неможливо відрізнити жодні два місця на решітці за ландшафтом.

3. Взаємодії локальні. Лише околишні клітинки (зазвичай сусідні) здатні вплинути на дану клітинку. 
4. Множина станів клітинки кінцева.

У двовимірному (площинному) випадку решітка реалізується двовимірним масивом. У ній кожна клітина має вісім сусідів. Для усунення крайових ефектів решітка може загортатися в тор. Це дозволяє використовувати таке співвідношення для всіх клітинок автомата:

$$
\begin{aligned}
& a_{i, j}^{\prime}=\varphi\left(a_{i, j}, a_{i-1, j}, a_{i-1, j+1}, a_{i, j+1}, a_{i+1, j+1},\right. \\
& \left.a_{i+1, j}, a_{i+1, j-1}, a_{i, j-1}, a_{i-1, j-1}\right)
\end{aligned}
$$

$\mathrm{У}$ цій роботі для моделювання процесу кристалізації клітинка може перебувати у двох станах: розплав і кристал.

Для переходу від детермінованого до ймовірнісного методу клітинних автоматів використовується така ідея. Правила переходу з одного стану стають недетермінованими. Перехід зі стану у стан відбувається 3 певною ймовірністю. На рисунку 1 наведено типові правила переходу $\varphi$ з погляду ймовірнісного методу.

Застосування такого ймовірнісного підходу дозволяє створити більш складні правила переходу зі стану у стан і зменшити вплив дискретності на результати роботи алгоритму.

3 фізичного погляду процес кристалізації повинен відбуватись рівномірно в усіх напрямках. Через локальні флуктуації та градієнти температури, нерівномірність за об'ємом хімічного складу розплаву кристалізація відбувається нерівномірно в різних напрямках. Для моделювання цього ефекту в роботі пропонується задавати швидкість кристалізації у вигляді еліпса. Радіуси еліпса відповідають швидкості кристалізації у відповідних напрямках. Для визначення ймовірностей переходу еліпс проєктується на клітинки поля. Після чого визначається площа еліпса, що потрапила в кожну клітинку (рис. 1д).

Для реалізації ймовірнісного методу кліткових автоматів було розроблено програмне забезпечення мовою програмування Python. Це програмне забезпечення працює за таким алгоритмом:

1. На першому кроці формується деякий дискретний простір.

2. На другому етапі випадковим чином із рівномірним розподілом обирається набір початкових клітинок. Їм встановлюється стан «кристал». Ці клітинки являють собою ядра зерен.
3. На третьому кроці алгоритму відбувається ріст зерна відповідно до правил переходу. Якщо клітинка являє собою кристал, то для всіх її сусідів генеруються випадкові числа в діапазоні $(0,1)$. Якщо число менше, ніж відповідна ймовірність, то клітинка переходить у стан «кристал». Інакше вона залишається в рідкому стані.

4. Крок 3 повторюється, доки не буде заповнено все поле.

\section{РЕЗУЛЬТАТИ МОДЕЛЮВАННЯ}

Як тестові приклади використовувались параметри мікроструктури чистого заліза. Зображення має розмір $513 \times 565$ пікселів. На зображенні - 714 зерен. Густина виникнення зерен становить $2,463 \times 10^{-3} \mathrm{px}^{-2}$. Ці параметри використовувались для моделювання методом клітинних автоматів. На рисунку 3 наведено результати генерації мікроструктури з різними околицями. Позиціями а - г позначено детерміновані околиці, д - е - імовірнісні. Імовірності для кола й еліпса показані на рисунку 4. Еліпс має відношення сторін 2/3, що приблизно відповідає параметрам правої детермінованої околиці.

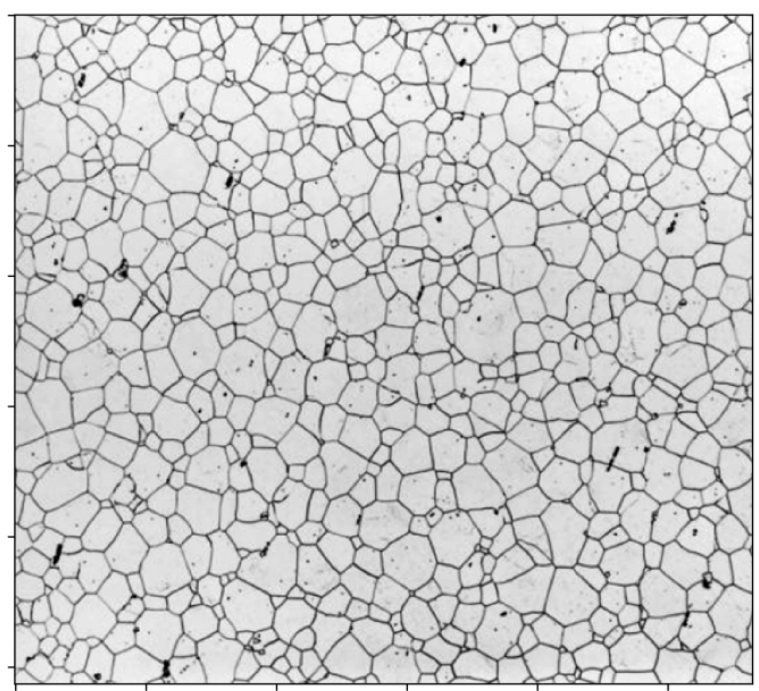

Рис. 2. Мікроструктура чистого заліза

Для кількісного аналізу схожості між мікроструктурами були обрані такі ознаки. Коефіцієнт форми $C_{s}$.

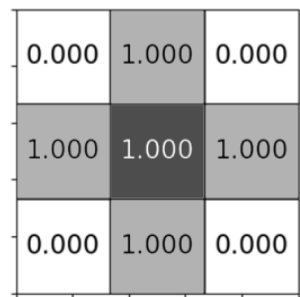

a

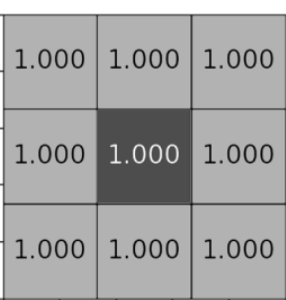

6

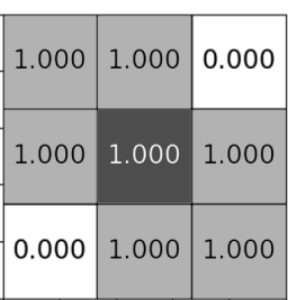

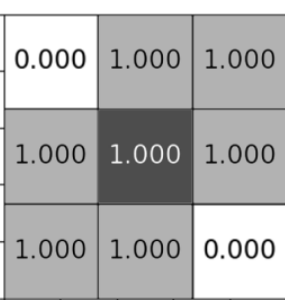

$\Gamma$

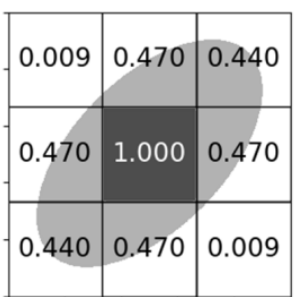

Д

Рис. 1. Околи клітинок [29]: а - Дж. фон Неймана; б - Е. Мура; с - лівого сусіда; д - правого сусіда; е - ймовірнісна 


\section{КОМП'ЮТЕРНІ НАУКИ ТА ІНФОРМАЦІЙНІ ТЕХНОЛОГІЇ №3ロ 2019}

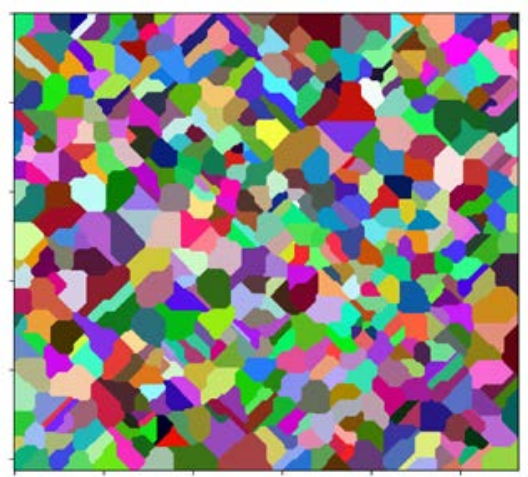

a

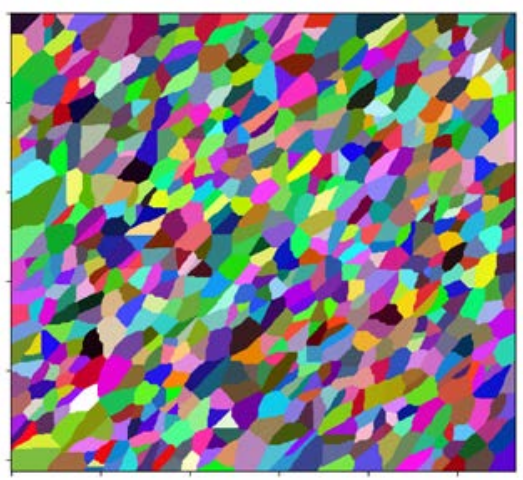

$\Gamma$

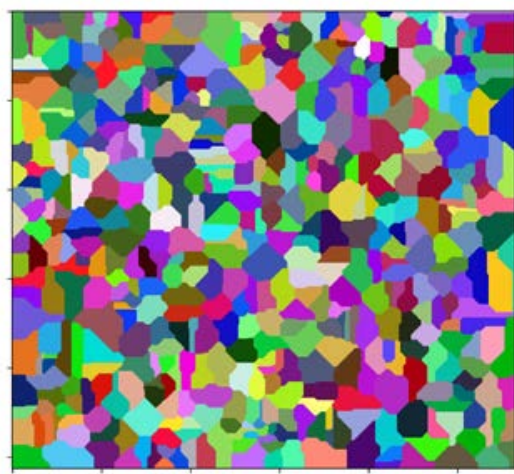

б

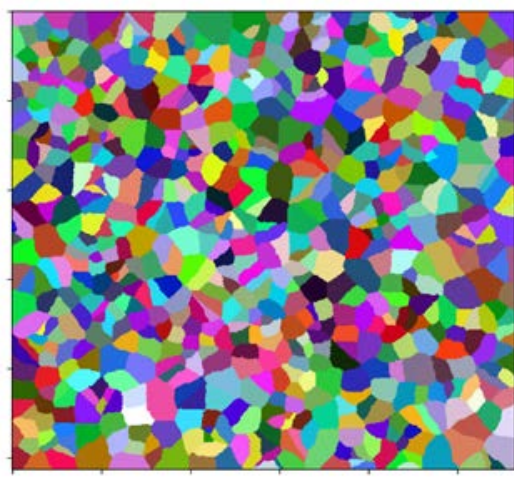

д

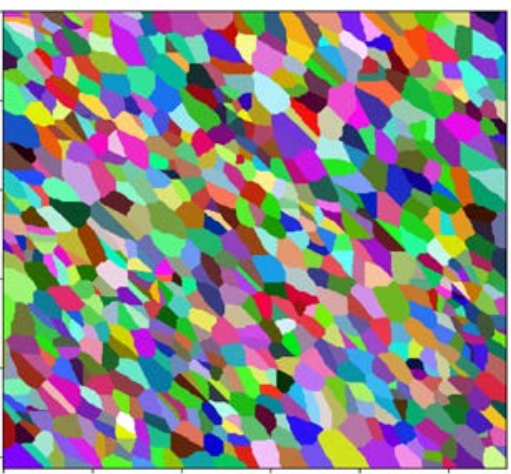

B

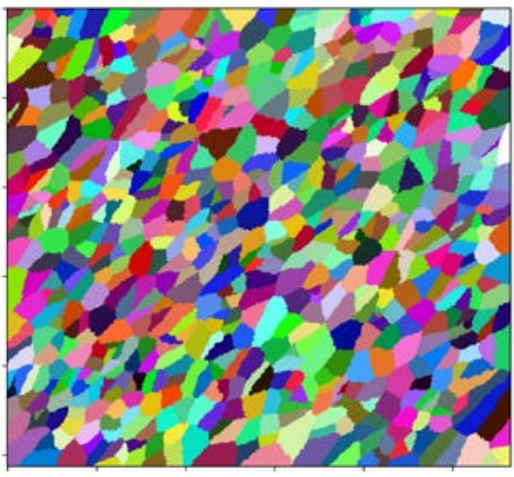

e

Рис. 3. Результати генерації мікроструктури методомкліткових автоматів із різними околицями: а - Е. Мура; б - Дж. фон Неймана; в - лівої околиці; г - правої околиці; д - імовірнісний метод (коло); е -імовірнісний метод (еліпс)

Цей коефіцієнт визначається як нормоване відношення площі зерна $A_{g r}$ до квадрата периметра зерна $P_{g r}$. Якщо зерно має форму кола, то $C_{s}=1$. Для всіх інших фігур $0<C_{s}<1$. Наприклад, для квадрата $C_{s}=\pi / 4=$ 0,7853 .

$$
C_{s}=4 \pi \frac{A_{g r}}{P_{g r}^{2}}
$$

\begin{tabular}{|l|l|l|}
\hline 0.543 & 0.970 & 0.543 \\
\hline 0.970 & 1.000 & 0.970 \\
\hline 0.543 & 0.970 & 0.544 \\
\hline
\end{tabular}

a

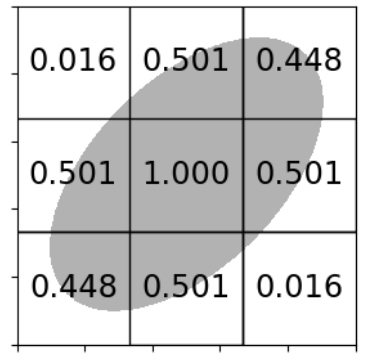

б
Рис. 4. Імовірності переходу околиці: а - круга; б - еліпса

Також за ознаку для порівняння обрано нормовану площу зерна $A_{n}$ як відношення площі зерна $A_{g r}$ до повної площі зображення $A$.

$$
A_{n}=\frac{A_{g r}}{A}
$$

Часто для порівняння параметрів зерен використовується масштабний коефіцієнт $S_{c}$. Він вводиться як відношення більшого характерного розміру зерна до меншого. Для визначення кута орієнтації зерен вводиться кут $\psi$, як кут між горизонталлю та найбільшим характерним діаметром зерна.

Для порівняння мікроструктур для кожного зерна сгенерованої мікроструктури обчислювались значення чотирьох коефіцієнтів. Ці значення статистично оброблялися і будувались гістограми. Ці гістограми були апроксимовані за допомогою методу визначення густини ядра [30]. Отримані апроксимовані густини ймовірності для зазначених коефіцієнтів наведені на рисунку 5.

Як видно з рисунків, розподіл параметрів дуже схожий. Однак спостерігаються деякі відмінності. 3 аналізу функції розподілу щільності ймовірності для параметра $C_{s}$ добре видно, що вліво зміщенні щільності для випадків, коли зерна мають більш витягнуту форму. До таких розподілів відносяться використання правої та лівої околиці, еліптичного ймовірнісного розподілу. Для інших випадків форми розподілу близькі одна з одною. Однак для мікроструктури зображення спостерігається більш довгий хвіст.

Під час порівняння розподілів параметра $A_{n}$ за різних способів генерації мікроструктури спостері- 

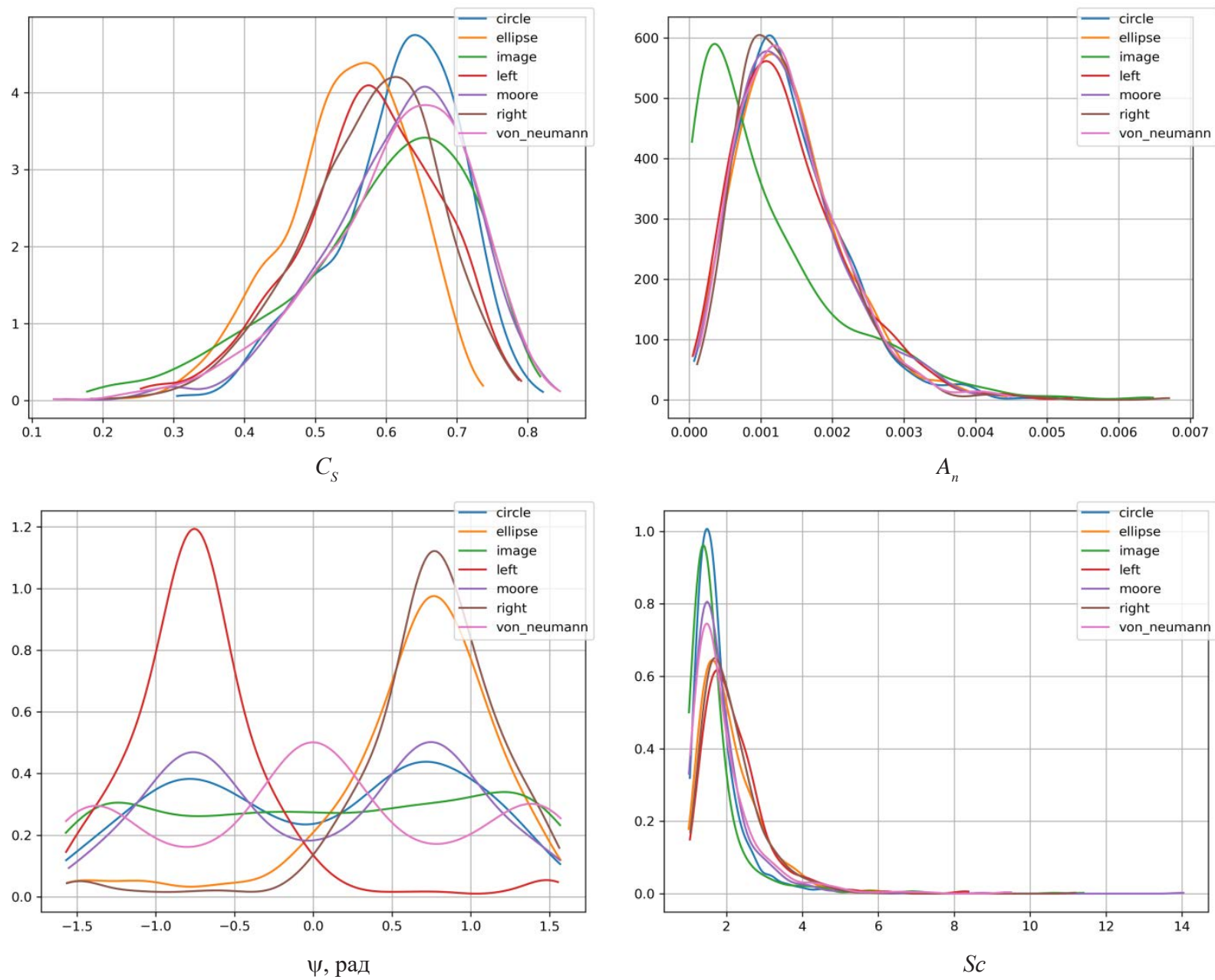

Рис. 5. Порівняння параметрів мікроструктури для різних типів околиць

гається, що всі синтетичні методи дають практично однаковий розподіл. Однак для мікроструктури 3 рис. 2 спостерігається зміщення розподілу вліво. Це вказує на неточності в запропонованій моделі кристалізації. Характеристики розподілу кута орієнтації зерен $\psi$ також значно залежать від способу генерації мікроструктури. Для зображення мікроструктури спостерігається практично рівномірний розподіл. Однак для детермінованих і ймовірнісних околиць характерні невеликі сплески функції щільності розподілу ймовірності для значень кутів $\pm \pi / 4$. Це, імовірно, пов'язано з використанням квадратної сітки методу клітинних автоматів.

За масштабним коефіцієнтом $S_{c}$ спостерігається найкращий збіг результатів. Відповідні детерміновані та ймовірнісні околиці добре узгоджуються між собою.

\section{ВИСНОВКИ}

У роботі розроблено реалізацію методу кліткових автоматів для детермінованих і ймовірнісних околиць. За розробленим методом показані результати генерації мікроструктури матеріалу.

Проведено порівняння отриманих мікроструктур чистого заліза із синтетичними мікроструктурами за коефіцієнтом форми, нормованою площею зерна, масштабним коефіцієнтом і кутом орієнтації зерна.

Результати порівняння показали, що щільності ймовірностей відповідних параметрів мають якісну схожість. Проте за параметром нормованої площі зерна розподіл для мікроструктури чистого заліза зміщений вліво.

\section{REFERENCES}

[1] Wolfram, S. (1986). Theory and applications of cellular automata: including selected papers, 1983-1986. Advanced series on complex systems; v. 1. World Scientific. https://doi.org/10.1109/ICPR.2010.378

[2] Schwartz, J. T., von Neumann, J., \& Burks, A. W. (1967). Theory of Self-Reproducing Automata. Mathematics of Computation. https://doi.org/10.2307/2005041 


\section{КОМП'ЮТЕРНІ НАУКИ ТА ІНФОРМАЦІЙНІ ТЕХНОЛОГІЇ № 3 2019}

[3] Wolfram, S. (2018). Cellular Automata and Complexity. CRC Press. https://doi.org/10.1201/9780429494093

[4] Nandi, S., Kar, B. K., \& Pal Chaudhuri, P. (1994). Theory and applications of cellular automata in cryptography. IEEE Transactions on Computers, 43(12), 1346-1357. https://doi.org/10.1109/12.338094

[5] Seredynski, F., Bouvry, P., \&Zomaya, A. Y. (2004). Cellular automata computations and secret key cryptography. Parallel Computing, 30(5-6), 753-766. https://doi.org/10.1016/J.PARCO.2003.12.014

[6] Hernández, G., \& Herrmann, H. J. (1996). Cellular Automata for Elementary Image Enhancement. Graphical Models and Image Processing. https://doi.org/10.1006/gmip.1996.0006

[7] Chen, R.-J., \& Lai, J.-L. (2007). Image security system using recursive cellular automata substitution. Pattern Recognition, 40(5), 1621-1631. https://doi.org/10.1016/J.PATCOG.2006.11.011

[8] Hyon, S. H., Torres, D., Groppa, R., Pekolj, J., Giudice, C., Litwak, L., \&Argibay, P. (1999). Transplantesimultáneo de páncreas y riñón. Medicina, 59(1), 93. Retrieved from http://citeseerx.ist.psu.edu/viewdoc/download?doi=10.1.1.13.455\&re $\mathrm{p}=$ rep1\&type $=$ pdf

[9] Rosin, P. L. (2006). Training cellular automata for image processing. IEEE Transactions on Image Processing, 15(7), 20762087. https://doi.org/10.1109/TIP.2006.877040

[10] Ermentrout, G. B., \& Edelstein-Keshet, L. (1993). Cellular automata approaches to biological modeling. Journal of Theoretical Biology. https://doi.org/10.1006/jtbi.1993.1007

[11] Xiao, X., Shao, S., Ding, Y., Huang, Z., Chen, X., \& Chou, K.-C. (2005). Using cellular automata to generate image representation for biological sequences. Amino Acids, 28(1), 29-35. https://doi.org/10.1007/s00726-004-0154-9

[12] Alber, M. S., Kiskowski, M. A., Glazier, J. A., \& Jiang, Y. (2003). On Cellular Automaton Approaches to Modeling Biological Cells (pp. 1-39). Springer, New York, NY. https://doi.org/10.1007/978-0-387-21696-6_1

[13] Vichniac, G. Y. (1984). Simulating physics with cellular automata. Physica D: Nonlinear Phenomena. https://doi. org/10.1016/0167-2789(84)90253-7

[14] Chopard, B. (2012). Cellular automata modeling of physical systems. In Computational Complexity: Theory, Techniques, and Applications. https://doi.org/10.1007/978-1-4614-1800-9_27

[15] Raabe, Dierk. (2002b). Cellular Automata in Materials Science with Particular Reference to Recrystallization Simulation. Annual Review of Materials Research, 32(1), 53-76. https://doi.org/10.1146/annurev.matsci.32.090601.152855

[16] Bakhtiari, M., \&SeyedSalehi, M. (2018). Reconstruction of deformed microstructure using cellular automata method. Computational Materials Science, 149, 1-13. https://doi.org/10.1016/J.COMMATSCI.2018.02.053

[17] Popova, E., Staraselski, Y., Brahme, A., Mishra, R. K., \&Inal, K. (2015). Coupled crystal plasticity - Probabilistic cellular automata approach to model dynamic recrystallization in magnesium alloys. International Journal of Plasticity, 66, 85-102. https://doi.org/10.1016/J.IJPLAS.2014.04.008

[18] Yazdipour, N., Davies, C. H. J., \& Hodgson, P. D. (2008). Microstructural modeling of dynamic recrystallization using irregular cellular automata. Computational Materials Science, 44(2), 566-576. https://doi.org/10.1016/J.COMMATSCI.2008.04.027

[19] Qian, M., \&Guo, Z. . (2004). Cellular automata simulation of microstructural evolution during dynamic recrystallization of an HY-100 steel. Materials Science and Engineering: A, 365(1-2), 180-185. https://doi.org/10.1016/J.MSEA.2003.09.025

[20] Zinoviev, A., Zinovieva, O., Ploshikhin, V., Romanova, V., \&Balokhonov, R. (2016b). Evolution of grain structure during laser additive manufacturing. Simulation by a cellular automata method. Materials \& Design, 106, 321-329. https://doi. org/10.1016/J.MATDES.2016.05.125

[21] Kühbach, M., Gottstein, G., \&Barrales-Mora, L. A. (2016a). A statistical ensemble cellular automaton microstructure model for primary recrystallization. ActaMaterialia, 107, 366-376. https://doi.org/10.1016/J.ACTAMAT.2016.01.068

[22] Reyes, L. A., Páramo, P., Salas Zamarripa, A., de la Garza, M., \& Guerrero Mata, M. P. (2015). Grain size modeling of a Ni-base superalloy using cellular automata algorithm. Materials \& Design, 83, 301-307. https://doi.org/10.1016/J. MATDES.2015.06.068

[23] Madej, L. (2017). Digital/virtual microstructures in application to metals engineering - A review. Archives of Civil and Mechanical Engineering, 17(4), 839-854. https://doi.org/10.1016/J.ACME.2017.03.002

[24] Akbari, M., Asadi, P., Givi, M. B., \&Zolghadr, P. (2016). A cellular automaton model for microstructural simulation of friction stir welded AZ91 magnesium alloy. Modelling and Simulation in Materials Science and Engineering, 24(3), 035012. https://doi.org/10.1088/0965-0393/24/3/035012

[25] Raabe, D. (2004). Mesoscale simulation of spherulite growth during polymer crystallization by use of a cellular automaton. ActaMaterialia, 52(9), 2653-2664. https://doi.org/10.1016/J.ACTAMAT.2004.02.013

[26] Zaharchuk, I. I. (2002). On the complexity of one-dimensional universal cellular automata. Discrete Analysis and Operations Research, 9(4), 50-56. Retrieved from http://www.mathnet.ru/rus/da185

[27] Zaharchuk, Iv. I, Zaharchuk, I. I., Veselov, Y. G., \&Ostrovskiy, A. S. (2013). Providing information protection for wireless sensor networks based on cellular automata. Engineering Journal: Science and Innovation, (11), 45. Retrieved from http:// engjournal.ru/articles/1003/html/files/assets/common/downloads/publication.pdf

[28] Naumov, L., \&Shalyto, A. (n.d.). SoftCraft: Cellular automata. Implementation and experiments. Retrieved November 22, 2018, from http://www.softcraft.ru/auto/switch/kla/

[29] Wang, W. (2003). A mathematical model of dendritic microstructures in nickel-based superalloys. Retrieved from https:// spiral.imperial.ac.uk/bitstream/10044/1/11524/2/Wang-W-2003-PhD-Thesis.pdf

[30] Silverman, B. W. (1986). Density Estimation for Statistics and Data Analysis. 


\section{СПИСОК ВИКОРИСТАНОЇ ЛІТЕРАТУРИ}

[1] Wolfram S. Theory and applications of cellular automata: including selected papers, 1983-1986. Advanced series on complex systems. V. 1. World Scientific. 1986. URL: https://doi.org/10.1109/ICPR.2010.378

[2] Schwartz J., von Neumann J., Burks A. Theory of Self-Reproducing Automata. Mathematics of Computation. 1967. DOI: $10.2307 / 2005041$.

[3] Wolfram S. Cellular Automata and Complexity. CRC Press. 2018. URL: https://doi.org/10.1201/9780429494093.

[4] Nandi S., Kar B., Pal Chaudhuri P. Theory and applications of cellular automata in cryptography. IEEE Transactions on Computers. 1994. № 43 (12). P. 1346-1357. URL: https://doi.org/10.1109/12.338094.

[5] Seredynski F., Bouvry P., Zomaya A. Cellular automata computations and secret key cryptography. Parallel Computing. 2004. № 30 (5-6). P. 753-766. DOI: 10.1016/J.PARCO.2003.12.014

[6] Hernández G., Herrmann H. Cellular Automata for Elementary Image Enhancement. Graphical Models and Image Processing. 1996. DOI: 10.1006/gmip.1996.0006

[7] Chen R.-J., Lai J.-L. Image security system using recursive cellular automata substitution. Pattern Recognition. 2007. № 40 (5). P. 1621-1631. DOI: 10.1016/J.PATCOG.2006.11.011.

[8] Transplante simultáneo de páncreas y riñón / S. Hyon et al. Medicina. 1999. № 59 (1). P. 93. URL: http://citeseerx.ist.psu. edu/viewdoc/download?doi=10.1.1.13.455\&rep=rep1\&type=pdf.

[9] Rosin P. Training cellular automata for image processing. IEEE Transactions on Image Processing. 2006. № 15 (7). P. 2076-2087. DOI: 10.1109/TIP.2006.877040.

[10] Ermentrout G., Edelstein-Keshet L. Cellular automata approaches to biological modeling. Journal of Theoretical Biology. 1993. DOI: 10.1006/jtbi.1993.1007.

[11] Using cellular automata to generate image representation for biological sequences / X. Xiao et al. Amino Acids. 2005 . № 28 (1). P. 29-35. DOI: 10.1007/s00726-004-0154-9.

[12] On Cellular Automaton Approaches to Modeling Biological Cells / M. Alber et al. Springer, New York, 2003. P. 1-39. DOI: 10.1007/978-0-387-21696-6_1.

[13] Vichniac G. Simulating physics with cellular automata. Physica D: Nonlinear Phenomena. 1984. DOI: 10.1016/01672789(84)90253-7.

[14] Chopard B. Cellular automata modeling of physical systems. In Computational Complexity: Theory, Techniques, and Applications. 2012. DOI: 10.1007/978-1-4614-1800-9_27.

[15] Raabe Dierk. Cellular Automata in Materials Science with Particular Reference to Recrystallization Simulation. Annual Review of Materials Research. 2002. № 32 (1). P. 53-76. DOI: 10.1146/annurev.matsci.32.090601.152855.

[16] Bakhtiari M., Seyed Salehi M. Reconstruction of deformed microstructure using cellular automata method. Computational Materials Science. 2018. № 149. P. 1-13. DOI: 10.1016/J.COMMATSCI.2018.02.053.

[17] Coupled crystal plasticity - Probabilistic cellular automata approach to model dynamic recrystallization in magnesium alloys / E. Popova et al. International Journal of Plasticity. 2015. № 66. P. 85-102. DOI: 10.1016/J.IJPLAS.2014.04.008.

[18] Yazdipour N., Davies C., Hodgson P. Microstructural modeling of dynamic recrystallization using irregular cellular automata. Computational Materials Science. 2008. № 44 (2). P. 566-576. DOI: 10.1016/J.COMMATSCI.2008.04.027.

[19] Qian M., Guo Z. Cellular automata simulation of microstructural evolution during dynamic recrystallization of an HY-100 steel. Materials Science and Engineering. 2004. A. 365 (1-2). P. 180-185. DOI: 10.1016/J.MSEA.2003.09.025.

[20] Evolution of grain structure during laser additive manufacturing. Simulation by a cellular automata method / A. Zinoviev et al. Materials \& Design. 2016. № 106. P. 321-329. DOI: 10.1016/J.MATDES.2016.05.125.

[21] Kühbach M., Gottstein G., Barrales-Mora L. A statistical ensemble cellular automaton microstructure model for primary recrystallization. Acta Materialia. 2016. № 107. P. 366-376. DOI: 10.1016/J.ACTAMAT.2016.01.068

[22] Grain size modeling of a Ni-base super alloy using cellular automata algorithm / L. Reyes et al. Materials \& Design. 2015. № 83. P. 301-307. DOI: 10.1016/J.MATDES.2015.06.068.

[23] Madej L. Digital/virtual microstructures in application to metals engineering : A review. Archives of Civil and Mechanical Engineering. 2017. № 17 (4). P. 839-854. DOI: 10.1016/J.ACME.2017.03.002.

[24] A cellular automaton model for microstructural simulation of friction stir welded AZ91 magnesium alloy / M. Akbari et al. Modelling and Simulation in Materials Science and Engineering. 2016. № 24 (3). DOI: 10.1088/0965-0393/24/3/035012.

[25] Raabe D. (Mesoscale simulation of spherulite growth during polymer crystallization by use of a cellular automaton. Acta Materialia. 2004. № 52 (9). P. 2653-2664. DOI: 10.1016/J.ACTAMAT.2004.02.013.

[26] Zaharchuk I. On the complexity of one-dimensional universal cellular automata. Discrete Analysis and Operations Research. 2002. № 9 (4). № № 50-56. URL: http://www.mathnet.ru/rus/da185.

[27] Providing information protection for wireless sensor networks based on cellular automata / I. Zaharchuk et al. Engineering Journal: Science and Innovation. 2013. № 11. P. 45. URL: http:/engjournal.ru/articles/1003/html/files/assets/common/ downloads/publication.pdf.

[28] Naumov L., Shalyto A. (n.d.). Soft Craft: Cellular automata. Implementation and experiments. November 22, 2018. URL: http://www.softcraft.ru/auto/switch/kla/.

[29] Wang W. A mathematical model of dendritic microstructures in nickel-based superalloys. 2003. URL: https://spiral.imperial. ac.uk/bitstream/10044/1/11524/2/Wang-W-2003-PhD-Thesis.pdf.

[30] Silverman B. Density Estimation for Statistics and Data Analysis. 1986. 